\title{
Studi Kebijakan dalam Optimalisasi Pajak dan Retribusi Parkir dalam Mendongkrak PAD di Kota Bandung
}

\author{
Deni Fauzi Ramdani*, Rodlial Ramdhan Tackbir Abubakar, Joni Dawud \\ Politeknik STIA LAN Bandung, Bandung, Indonesia \\ Email: ${ }^{1, *}$ deni.fauzi@ poltek.stialanbandung.ac.id, ${ }^{2}$ rodlial.ramdhan@stialanbandung.ac.id, \\ 3jonidawud@poltek.stialanbandung.ac.id \\ Email Penulis Korespondensi: deni.fauzi@ poltek.stialanbandung.ac.id \\ Submitted: 22/11/2021; Accepted: 29/11/2021; Published: 30/11/2021
}

\begin{abstract}
Abstrak-Pajak dan retribusi parkir merupakan bagian penting sebagai unsur penerimaan daerah. Adanya desentralisasi mendorong daerah untuk terus berupaya melakukan optimalisasi yang bisa meningkatkan pendapatan. Artikel ini mencoba menggali dengan menelaan kebijakan dan inovasi yang dilakukan oleh pemerintah Kota Bandung sebagai upaya meningkatkan pendapatan asli daerah. Pajak dan retribusi parkir sebagai pencapaian target yang diharapkan. Artikel ini sebagai kajian kebijakan dalam pengelolaan keuangan daerah Penelitian ini menggunakan metode penelitian dengan pendekatan deskriptif Kualitatif dengan pengumpulan data primer dan sekunder dari informan. Hasilnya ada Kebijakan yang diambil oleh pemerintah Kota Bandung dengan melakukan proses Kebijakan elastisitas dan efektivitas untuk mendongkrak dan meningkatkan pendapatan dari pajak dan retribusi parkir.
\end{abstract}

Kata Kunci: Kebijakan; Retribusi; Pajak

Abstract-Parking taxes and retribution are an important part as an element of regional revenue. The existence of decentralization encourages regions to continue to make optimizations that can increase income. This article tries to explore by examining the policies and innovations carried out by the Bandung City government as an effort to increase local revenue. Parking taxes and retribution as the achievement of the expected target. This article is a policy study in regional financial management. This research uses a qualitative descriptive approach with primary and secondary data collection from informants. The result is a policy taken by the Bandung City government by carrying out the elasticity and effectiveness policy process to boost and increase revenue from taxes and parking fees.

Keywords: Policy; Retribution; Tax

\section{PENDAHULUAN}

Desentralisasi sebagai salah satu asas otonomi daerah, hal ini diimplementasikan untuk aplikasi demokratisasi di Indonesia (Sulila, 2015). Transformasi desain tata Kelola pemerintahan dari sentralisasi yang sangat berdampak terhadap tidak adanya ruang bagi masyarakat untuk dapat memunculkan potensi di daerah yang sebenarnya sangat dibutuhkan. Oleh karena itu, Asas desentralisasi dilaksanakan menjadi jawaban dengan tujuan terciptanya pembagian kekuasaan antara pemerintah pusat dengan pemerintah daerah supaya daerah bisa menggali sebesarbesarnya potensi yang dimiliki.

Ditetapkannya Undang-Undang No. 23 tahun 2014 tentang Pemerintahan Daerah dan Undang-Undang No. 33 tahun 2004 tentang Perimbangan Keuangan antara Pemerintah Pusat dan Pemerintah Daerah memberikan lebih banyak kewenangan kepada Pemerintah Daerah untuk menjalankan fungsi pemerintahan. Undang-Undang tersebut merupakan landasan bagi pelaksanaan Otonomi Daerah di Indonesia. Otonomi daerah membuka peluang adanya reformasi yang dijalankan oleh setiap daerah agar dapat melakukan pelayanan yang lebih baik kepada masyarakat. Selain itu, pemerintah daerah dituntut untuk berinovasi dalam mencari sumber penerimaan daerah yang dapat digunakan untuk membiayai pengeluaran Pemerintah Daerah dan pembangunan (Rante, Mire, \& Paminto, 2018). Setiap daerah tersebut memiliki kewenangan dalam mengurus dan mengatur rumah tangganya sendiri untuk tujuan meningkatkan efisiensi dan efektifitas dalam menyelenggarakan Pemerintahan (Sidik, 2002).

Pengelolaan Pendapatan Asli Daerah (PAD) sebagai bagian dari keuangan daerah berhubungan erat dengan implementasi konsep desentralisasi didalam penyelenggaraan urusan pemerintahan di daerah. Adanya kebijakan desentralisasi, Sebagian urusan pemerintah pusat diserahkan kepada pemerintahan daerah dalam rangka menciptakan perubahan didalam penyelenggaraan pemerintahan dan membangun daerah sesuai dengan potensi dan kekhasan yang dimiliki oleh masing-masing daerah. Ditetapkannya Undang-undang Nomor 23 Tahun 2014 tentang Pemerintahan Daerah sebagai perubahan UU mengenai pemerintah daerah dari UU. No. 22 Tahun 1999 dan UU. No. 32 Tahun 2004 memberikan kewenangan kepada pemerintah daerah untuk mengelola keuangan daerah. Kebijakan ini dimaksudkan untuk meningkatkan pelayanan pemerintahan kepada masyarakatnya agar semakin prima. Untuk mencapai tujuan tersebut, maka diperlukan kesiapan anggaran yang relatif cukup besar, sehingga daerah diharapkan mampu menggali berbagai potensi untuk meningkatkan Pendapatan Asli Daerah (PAD). Sumber PAD tersebut antara lain terdiri dari : (1) pajak daerah, (2) retribusi daerah, (3) bagian lain BUMD, (4) penerimaan lain-lain PAD yang sah (Horota, Riani, \& Marbun, 2017).

Pendapatan Asli Daerah adalah satu-satunya sumber yang benar-benar murni dikelola oleh Pemerintah Daerah, oleh karena itu, keberhasilan daerah dalam otonomi daerah dapat dilihat dari penerimaan dana dari sektor ini (Sutardi, 2005). Diantara sumber pendapatan daerah yang penting dari sekian sumber pendapatan tersebut adalah pajak dan retribusi daerah, karena setiap tahunnya pajak dan retribusi daerah mampu memberikan sumbangan yang 
cukup besar bagi penerimaan daerah. Salah satu jenis pajak dan retribusi yang dipungut oleh Pemerintah Daerah adalah retribusi parkir.

Pajak daerah merupakan salah satu sumber utama penerimaan keuangan daerah dalam komponen Pendapatan Asli Daerah. Badan Penerimaan Pendapatan Daerah Kota Bandung merupakan salah satu Organisasi Perangkat Daerah Di Kota Bandung yang bertugas untuk mengelola salah satu sumber pendapatan asali daerah salah satunya adalah Pajak parkir off street yang mana jenis ini adalah tempat parkir yang berada di luar badan jalan, misalnya di halaman gedung, di ruang bawah tanah, atau pada tempat yang dikhususkan untuk menjadi taman parkir sebagaimana telah diatur di dalam Peraturan Daerah Kota Bandung Nomor 6 Tahun 2016 tentang Pajak Daerah dan Peraturan Daerah. Salah satu upaya dalam meningkatkan PAD Kota Bandung, Badan Penerimaan Pendapatan Daerah Kota Bandung, melihat potensi pajak parkir off street memiliki potensi yang besar untuk dapat menyumbangkan penerimaan bagi daerah. Adapun realisasi penerimaan pajak parkir di Kota Bandung dalam kurun waktu 5 tahun terakhir adalah sebagai berikut :

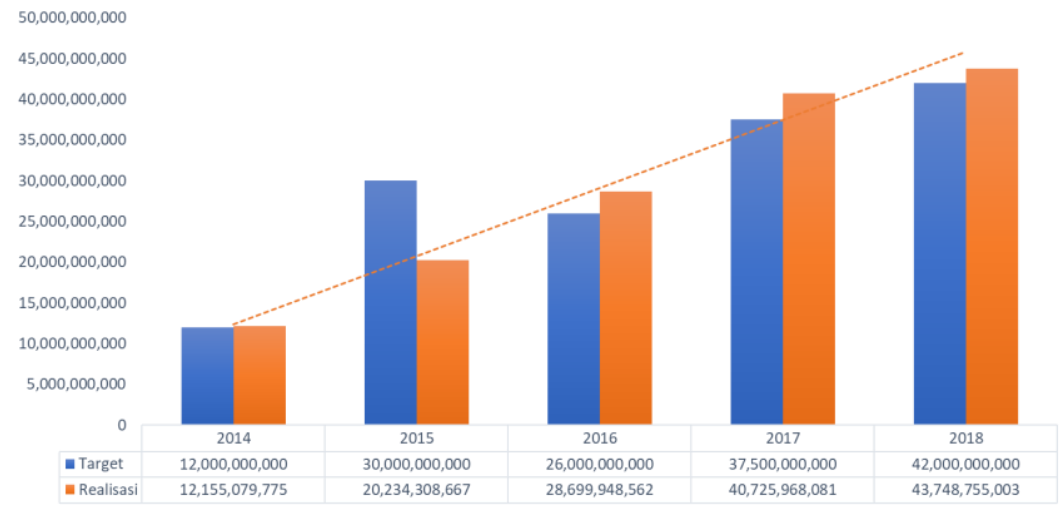

Gambar 1. Grafik Target dan Realisasi Pajak BPPD Kota Bandung Tahun 2014-2018 Sumber : BPPD Kota Bandung, 2020

Berdasarkan grafik yang tertera pada gambar 1, maka dapat diketahui bahwa realisasi pajak parkir di Kota Bandung selama 5 tahun yaitu dari tahun 2014-2018 mengalami peningkatan secara signifikan setiap tahunnya. Hal ini menunjukan bahwa potensi pajak parkir akan selalu meningkat setiap tahunnya seiring dengan bertambahnya jumlah kendaraan dan Gedung yang memiliki potensi untuk menjadi wajib pajak parkir.

Dibalik peningkatan pajak dan retribusi parkir setiap tahunnya, perlu kita ketahui bahwa terdapat permasalahan klasik terkait dengan pajak dan retribusi parkir khususnya di Kota Bandung yang sampai sekarang belum kunjung ada solusinya. Mulai dari penerimaan pajak dan retribusi parkir yang masih banyak menemukan kendala dalam pengelolaannya dimana masih banyak kawasan parkir yang strategis tetapi tidak terdaftar di Pemerintah Daerah, sampai kepada adanya pihak/ oknum yang mengaku sebagai putra daerah atau ormas tertentu yang kurang bertanggungjawab dengan menggunakan kesempatan tersebut untuk meraup keuntungan padahal pihak/ oknum tersebut belum terdaftar sebagai juru parkir pada Dinas Perhubungan Kota Bandung.

Masalah lain yang menjadi kendala dalam pemungutan pajak dan retribusi parkir adalah belum optimalnya pemungutan yang dilakukan secara langsung, online, ataupun secara elektronik melalu mesin parkir elektronik yang ada di Kota Bandung. Selain itu juga terdapat beberapa oknum juru parkir yang tidak menyetorkan retribusi parkir sesuai dengan potensi/ target yang telah ditentukan sebelumnya. Untuk itu perlu ada terobosan kebijakan yang dapat mendongkrak upaya peningkatan PAD dalam optimalisasi pengelolaan keuangan daerah (Harefa, Permana, Mangeswuri, \& Meilani, 2018).

\section{METODE PENELITIAN}

Lokasi penelitian adalah di Kota Bandung dan Kota Cimahi, yaitu secara khusus pada Badan Penerimaan dan Pendapatan Daerah Kota Bandung, Dinas Perhubungan Kota Bandung, Badan Pendapatan Daerah Kota Bandung, Badan Pendapatan Daerah Kota Cimahi, dan Dinas Perhubungan Kota Cimahi. Adapun alasan yang mendasari penulis memilih Kota Bandung dan Kota Cimahi sebagai obyek penelitian tentang studi kebijakan optimalisasi pajak dan retribusi parkir di Kota Bandung dan Kota Cimahi.

Artikel ini menggunakan metode dengan pendekatan deskriptif kualitatif yang berupaya mendeskripsikan kebijakan kebijakan optimalisasi pajak dan retribusi parkir, sedangkan teknik pengumpulan data dilakukan melalui inventarisasi data primer dan sekunder. Pengumpulan data primer diperoleh dari data empiris lapangan melalui Teknik wawancara mendalam (depth interview) dan observasi non partisipan terhadap para pemangku kepentingan (steakholders) berkaitan langsung dengan informan yang terlibat dalam pengelolaan pajak dan retribusi parkir. Data sekunder diperoleh melalui penelusuran berbagai dokumen pemerintah, literatur, pemberitaan media massa cetak dan elektronik, jurnal dan buku-buku yang terkait dengan kebijakan pajak dan retribusi parkir sebagai fakta yang 
terjadi dalam upaya pencarian data dilapangan. Selanjutnya data yang terkumpul, dianalisis dengan analisis kualitatif berdasarkan model interaktif Miles dan Huberman (Arikunto, 2010).

Informan dalam penelitian adalah orang atau pelaku yang benar-benar tahu dan menguasai masalah, serta terlibat lansung dengan masalah penelitian. Dengan mengunakan metode penelitian kualitatif, maka peneliti sangat erat kaitannya dengan faktor-faktor kontekstual. Jadi dalam hal ini sampling dijaring sebanyak mungkin informasi dari berbagai sumber. Maksud kedua dari informan adalah untuk menggali informasi yang menjadi dasar dan rancangan teori yang dibangun.

Pemilihan informan sebagai sumber data dalam penelitian ini adalah berdasarkan pada asas subyek yang menguasai permasalahan, memiliki data, dan bersedia memberikan informasi lengkap dan akurat. Informan yang bertindak sebagai sumber data dan informasi harus memenuhi syarat, oleh karena itu yang menjadi informan narasumber (key informan) dalam penelitian ini adalah :

1. Kepala Sub Bidang Pajak dan Hibutan dan Pajak Parkir Badan Penerimaan dan Pendapatan Daerah

2. Kepala Bidang Penerimaan dan Pengendalian Badan Pendapatan Daerah Kota Cimahi

3. Kepala Seksi Perparkiran Dinas Perhubungan Kota Cimahi

4. Koordinator Wilayah Tegalega Dinas Perhubungan Kota Bandung

5. Kepala BLUD UPT Pengelolaan Perparkiran Dinas Perhubungan Kota Bandung.

Penelitian kualitatif tidak mempersoalkan jumlah informan, tetapi bisa tergantung dari tepat tidaknya pemilihan informan kunci, dan kompleksitas dari keragaman fenomena sosial yang diteliti. Dengan demikian, informan ditentukan dengan teknik snowball sampling, yakni proses penentuan informan berdasarkan informan sebelumnya tanpa menentukan jumlahnya secara pasti dengan menggali informasi terkait topik penelitian yang diperlukan

\section{HASIL DAN PEMBAHASAN}

\subsection{Potensi Pajak dan Retribusi Parkir}

Pemerintah Kota Bandung dalam pengelolaan pajak dan retribusi parkir sesuai dengan ketentuan Undang-undang yang sudah dijabarkan diatas dilaksanakan oleh dua instansi. Kewenangan pajak parkir pemungutannya dilaksanakan oleh Badan Pengelolaan Pendapatan Daerah (BPPD), sedangkan untuk Retribusi parkir kewenangan sepenuhnya dilaksanakan oleh Dinas Perhubungan. Potensi pajak parkir sebenarnya masih belum tergali dengan baik, kendala diakui menjadi penghambat diantaranya adalah mengenai kesadaran wajib pajak yang tidak melakukan pelaporan dengan baik dan sejumlah masalah lainnya.

Kota Bandung dalam urusan potensi pajak parkir ada beberapa data yang menarik diantaranya adalah identifikasi masalah kesadaran penyelenggara parkir dalam memenuhi kewajiban perpajakan daerah masih perlu ditingkatkan, terutama penyelenggara parkir yang tidak melakukan pemungutan sewa parkir kepada penerima jasa parkir. Masih terdapat wajib pajak parkir yang telah ditetapkan secara jabatan namun belum memenuhi kewajiban perpajakannya. Ini merupakan potensi yang masih belum tergali secara optimal.

Potensi pajak parkir terus ditingkatkan oleh BPPD Kota Bandung dengan intensifikasi dan ekstensifikasi pajak. Meskipun petugas lapangan hanya 7 orang tetapi Bapenda selalu mengedepankan kolaborasi dengan 5 UPT Bapenda dan dengan kantor kewilayahan yaitu kecamatan dan kelurahan. Tugasnya melakukan pendataan dan pelaporan terhadap potensi pajak parkir yang belum tergarap yaitu tempat penitipan kendaraan bermotor. Setelah mendapatkan pelaporan pihak BPPD berkirim surat dan meminta calon Wajib Pajak memenuhi ketentuan untuk melakukan pelaporan dan pembayaran pajak parkir.

Kajian awal menyebutkan potensi pendapatan dari parkir on street 85 Milyar oleh salahsatu perguruan tinggi. Namun hasil kajian tersebut masih dipertanyakan hingga muncul angka tersebut dari mana? Padahal banyak sekali aspek yang harus dilihat ketika pengelolaan parkir dijalankan. Karena parkir bisa dikatakan menyangkut hajat hidup banyak orang. Kurangnya pemetaan masalah sejak awal sehingga parkir elektronik yang dijalankan saat ini menjadi terkendala. Berdasarkan sumber informan dalam beberapa titik saja setidaknya harus memperhitungkan siapa saja yang terlibat langsung. Karena bukan hanya juru parkir saja ada ormas, ada oknum aparat atau pihak lain yang mempengaruhi seberapa besar uang parkir yang harus disisihkan. Meskipun umpamanya dalam satu titik pakir ada yang secara rutin meminta jatah rokok yang nilainya tidak seberapa tetapi kalau diakumulasikan akan mempengaruhi kinerja juru parkir.

Meskipun pengawasan kerja terhadap juru parkir, Kepala Sektor juga dilakukan oleh pihak Unit Pengelola Perparkiran. Metode pengawasan oleh Petugas BLU Perparkiran ini dilakukan secara berkala, setiap kali penarikan setoran, setiap harinya yang dilakukan oleh bagian Kepala Sektor (Kator). Apabila terdapat pelanggaran yang ditemui, baik itu yang dilakukan oleh juru parkir. Pada kenyataannya berbagai strategi yang dilakukan untuk mengelola perparkiran Kota Bandung belum dapat dilaksanakan secara maksimal. Permasalahan yang ada tidak hanya mengenai jumlah dana yang masuk ke kas daerah, melainkan terkait dengan ketertiban, keamanan, keindahan dan kelancaran lalu lintas.

Pengadaan dilakukan dengan skema Pemerintah melakukan swakelola oleh UPT Parkir. 445 Mesin parkir dioperasikan mulai tahun 2017. Setelah satu bulan beroperasi pendapatan parkir tidak mengalami perubahan yang signifikan. Ternyata pada prakteknya banyak kendala yang terjadi di lapangan. Sehingga skema yang muncul saat 
ini tidak memberikan nilai tambah pada peningkatan PAD yang ditargetkan. Permasalahan mulai dari tidak disiplinnya juruparkir, tingkat kesadaran masyarakat dan banyak kelompok kepentingan yang memperkeruh sistem penglolaan parkir tidak berjalan dengan baik

\subsection{Kebijakan Elastisitas dan Efektifitas}

Elastisitas yatu tingkat kepekaan perubahan penerimaan retribusi jika terjadi perubahan pada kondisi tertentu. Hal ini dilakukan oleh kedua lokus baik di Kota Bandung maupun Kota Cimahi. Kota Bandung melakukan perubahan dalam bentuk regulasi maupun kelembagaan dan penempatan tehnologi sebagai sebuah inovasi.

Diantaranya dalam menghadapai kondisi pandemic ini pemerintah Kota Bandung melakukan perubahan kebijakan dalam penerimaan pajak dalam rangka untuk meningkatkan kembali capaian penerimaan pajak parkir pemerintah Kota Bandung melakukan langkah-langkah diantaranya menyusun Perwal No. 42 tahun 2020 tentang Pemberian Insentif Pajak Daerah dalam rangka penanganan dampak ekonomi corona virus disease 2019. Sosialisasi peraturan wali kota bandung nomor 42 tahun 2020 dibarengi dengan Kebijakan insentif pajak daerah berupa penghapusan sanksi administratif diharapkan mampu meningkatkan pendapatan dari piutang pajak.

Selain itu demi mempermudah dan meningkatkan kualitas pelayanan dalam pelaporan pajak di Badan Pengelolan Pendapatan Daerah cukup dengan melakukan pelaporan secara electronic dengan menggunakan E-Satria (Self Assessment Tax Reporting Application). Aplikasi ini bisa mempermudah segala urusan pembayaran pajak dengan memutus sistem transaksi tatap muka. Sehingga wajib pajak dengan pegawai yang kerap menjadi celah pungli tidak saling bertemu.

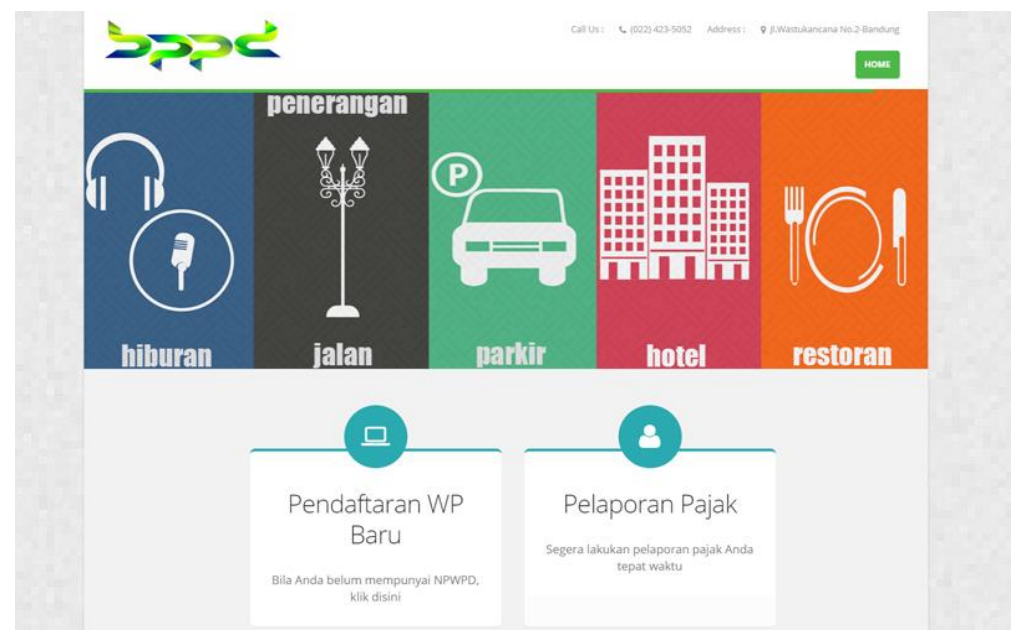

Gambar 2. Aplikasi E-Satria Memudahkan Pelaporan Pajak

E-Satria, ini sebuah inovasi untuk mempermudah wajib pajak dalam membayar kewajibannya tanpa harus mendatangi kantor BPPD. Awalnya seluruh Wajib pajak harus datang ke kantor pajak untuk melaporkan kewajiban pajaknya dimana hal ini membutuhkan waktu dan biaya bagi wajib Pajak dan mengakibatkan antrian di kantor Pajak. Kini WP diberikan alternative bagi yang memiliki banyak aktivitas kerja maka aplikasi ini memberikan kemudahan. Selain itu E-satria ini mendekatkan layanan sehingga mempermudah Wajib Pajak dalam melaporkan kewajiban pajaknya tanpa harus datang ke kantor pelayanan pajak sehingga dapat menghilangkan antrian dan kontak antara petugas dengan Wajib Pajak. Manfaat dari inovasi e- Satria :

a. e-satria ini memfasilitasi pelaporan pajak hiburan, penerangan jalan, Parkir, Hotel, dan Restoran, e-SATRIA ini diharap dapat mengubah kultur atau kebiasaan dari yang biasanya terjadi kontak langsung Wajib Pajak dengan para petugas menjadi tidak ada kontak langsung

b. Memberikan kemudahan bagi wajib pajak dalam melaporkan kewajiban pajak nya dan kemudahan dalam pembayarannya

c. Bagi petugas lebih memudahkan karena tidak harus lagi melakukan input data pelaporan dari Wajib Pajak karena input data sudah dilakukan oleh Wajib Pajak Sendiri

Saat ini belum merambah pada apliaksi untuk smartphone dan menjadi potensi untuk pengembangan dapat dibuat versi untuk smartphone, karena saat ini baru bisa diakses melalui web memungkinkan juga untuk di replikasi. Upgrade aplikasi baik tampilan ataupun fasilitas untuk mempermudah dalam pengisian form laporan wajib pajak.Sumber Daya Yang Digunakan Server dan Jaringan Internet yang Baik.

Sementara retribusi parkir dalam pengelolaannya sudah dilaksanakan dengan menggunakan parkir elektronik. Meskipun setelah peneliti gali kebijakan ini mengalami stagnasi dalam penerapannya karena menemukan banyak kendala. Kajian awal menyebutkan potensi pendapatan dari parkir on street 85 Milyar oleh salahsatu perguruan tinggi. Namun hasil kajian tersebut masih dipertanyakan hingga muncul angka tersebut dari mana? Padahal banyak sekali aspek yang harus dilihat ketika pengelolaan parkir dijalankan. Karena parkir bisa dikatakan menyangkut hajat hidup banyak orang. Kurangnya pemetaan masalah sejak awal sehingga parkir elektronik yang dijalankan saat ini menjadi terkendala. Berdasarkan sumber informan dalam beberapa titik saja setidaknya harus 
memperhitungkan siapa saja yang terlibat langsung. Karena bukan hanya juru parkir saja ada ormas, ada oknum aparat atau pihak lain yang mempengaruhi seberapa besar uang parkir yang harus disisihkan. Meskipun umpamanya dalam satu titik pakir ada yang secara rutin meminta jatah rokok yang nilainya tidak seberapa tetapi kalau diakumulasikan akan mempengaruhi kinerja juru parkir.

Meskipun pengawasan kerja terhadap juru parkir, Kepala Sektor juga dilakukan oleh pihak Unit Pengelola Perparkiran. Metode pengawasan oleh Petugas BLU Perparkiran ini dilakukan secara berkala, setiap kali penarikan setoran, setiap harinya yang dilakukan oleh bagian Kepala Sektor (Kator). Apabila terdapat pelanggaran yang ditemui, baik itu yang dilakukan oleh juru parkir. Pada kenyataannya berbagai strategi yang dilakukan untuk mengelola perparkiran Kota Bandung belum dapat dilaksanakan secara maksimal. Permasalahan yang ada tidak hanya mengenai jumlah dana yang masuk ke kas daerah, melainkan terkait dengan ketertiban, keamanan, keindahan dan kelancaran lalu lintas.

Diperlukan adanya komitmen bersama bukan hanya pimpinan saja tapi Koordinator parkir dan juru parkir yang menjadi ujung tombak harus punya komitmen yang tinggi dalam kelancaran program ini. Pengoperasian dan pemeliharaan dengan swakelola tidak akan berjalan dengan baik apabila Sumber Daya Manusia nya tidak punya komitmen. Salahsatu permasalahan ini menjadi mengemuka karena ketika dilakukan perbaikan-perbaikan mekanisme dilakukan oleh dinas perhubungan salahsatunya dengan melakukan rotasi juru parkir banyak yang keberatan. Salahsatu informan menyampaikan kalau masih dilakukan skema pengelolaan oleh pemerintah pasti permasalahan seperti ini tetap ada.

Selanjutnya kesadaran masyarakat dalam penggunaan parkir elektronik masih tetap rendah. Terbukti dari observasi yang dilakukan dalam satu minggu hanya satu atau dua masyarakat yang melakukan pembayaran secara elekronik. Ini juga menyangkut keseriusan pemerintah dalam memberikan pelayanan. Sebenarnya sudah dilakukan audit dibeberapa titik. Permasalahannya teridentifikasi beberapa hal pertama, tidak setiap masyarakat yang melakukan parkir mempunyai kartu e tol dan sudah dibuka beberapa outlet agar masyarakat bisa mudah membeli kartu. Kedua, juru parkir harusnya menjadi kepanjangan tangan dari petugas dinas perhubungan. Juru Parkir mengarahkan setiap masyarakat untuk melakukan proses transaksi dengan parkir elektronik. Kalau tidak mengikuti arahan bisa dikenakan sanksi.

Tantangan berikutnya adalah mengenai kepemimpinan kepala daerah juga merupakan faktor penting dalam kelancaran kebijakan yang diimplementasikan. Sampai akhir masa jabatan Ridwan Kamil sebagai walikota memantau terus perkembangan parkir elektronik hingga bisa diimplemantasikan meskipun pada periode kepemimpinannya cenderung top-down harus mengikuti arahan dari pilihan kebijakan yang sudah diputuskannya. Hal ini terungkap dalam wawancara dengan salahsatu informan sampai-sampai kepala dinas meminta kepala UPT Parkir mengumpulkan langsung para kepala sector (kator) dan para koodinantor juru parkir. "Setelah memberi pemahaman visi perparkiran, saya memberi arahan setengah otoriter . ini dilakukan karena pembinaan seperti ini bukan kali pertama".

Selain tantangan, peluang dalam pengelolaan parkirpun ada diantaranya adalah kondisi Kota Bandung sebagai ibu kota provinsi dengan kultur daerah perkotaan tentu sangat mudah untuk melakukan sosialisasi dan adaptasi perubahan perilaku. Potensi yang saat ini belum tergali dengan 445 mesin parkir elektronik bisa menjadi fasilitas pendongkrak kenaikan pendapatan.

Selain itu, peluang lainnya adalah dukungan secara politik diberikan oleh DPRD Kota Bandung untuk memperbaiki sistem pengelolaan parkir sehingga dapat meningkatkan PAD. Pada awalnya yang mendorong pembelian mesin parkir memang didorong oleh kajian perguruan tinggi yang berkerjasama dengan anggota DPRD Kota Bandung. Pada saat pembahasan Laporan Pertanggungjawaban (LPJ) Walikota ada pembahasan anggaran mesin parkir Rp. 80 Milyar. Ternyata anggaran tersebut merupakan hasil pembahasan dengan Badan Anggaran DPRD. Pembahasan ditujukan untuk menindaklanjuti dan mendukung pendapaian hasil kajian yang menyebutkan potensi parkir on street di Kota Bandung sebesar Rp. 80 Milyar.

Pada waktu itu berbarengan dengan pergantian Kepala Dinas Perhubungan. Keputusannya Kepala Dinas Perhubungan yang baru tidak bolehmenghapus kebijakan yang telah disepakati bersama. Akhirnya dilakukanlah pengadaan sebesar Rp.53 Milyar dan sisanya untuk operasional.

Permasalahan pun terjadi setelah terpasang akhir tahun 2016, mesin parkir tak segera beroperasi. Argumentasi Kepala Dinas pada waktu itu tidak mendapatkan informasi yang memadai. Untuk bisa operasional ternyata harus ada proses tambahan pengadaan integrator, reader, dan tentu kerjasama dengan bank-bank pemegang uang elektronik.

Pengesahan anggaran tahun 2017 sudah dilakukan dan tidak teranggarkan . maka melakukan pergeseran anggaran pada bulan maret 2017. Proses eksekusi anggaran baru dilaksanakan setelahnya, sehingga reader dan jasa integrator baru bisa mulai kontrak dibulan juni. Sehingga pada bulan juli mesin parkir bisa beroperasi .

Pendapatan akhir tahun dari hasil pengelolaan parkir elektronik yang dimulai bulan juli hanya mengalami peningkatan Rp 1 Milyar dari tahun sebelumnya. Dari angka mendekati Rp. 5 milyar menjadi mendekati Rp. 6 Milyar jauh dari ekspektasi target 80 milyar.

Awal tahun 2018 mengalami kenaikan kumulatif . tetapi bulan berikutnya tidak mengalami kenaikan bahkan turun. Selanjutnya dilakukan audit lapangan dan setelah dilakukan audit ternyata hampir semua titik terjadi ketidaksesuain prosedur setiap pemilik kendaraan membayar dengan cara cash. 
Selanjutnya kepala dinas menghentikan audit selanjutnya mefokuskan pembentukan Badan Layanan Umum Daerah (BLUD) dan perubahan peraturan daerah tentang penyelenggaraan perhubungan. Perubahan kelembagaan dari Unit Pelaksana Teknis (UPT) Parkir menjadi Badan Layanan Umum sebenarnya satu tahap menuju arah manajemen yang lebih luwes. Karena dalam skema kerjasama Pemerintah-Swasta diperlukan keluwesan dalam melakukan tata kelola. Aturan pemerintah sudah memfasilitasi Undang-undang Nomor 23 Tahun 2005 tentang Pengelolaan Keuangan Badan Layanan Umum dinyatakan bahwa : "Badan Layanan Umum adalah instansi di lingkungan Pemerintah yang dibentuk untuk memberikan pelayanan kepada masyarakat berupa penyediaan barang dan/atau jasa yang dijual tanpa mengutamakan mencari keuntungan dan dalam melakukan kegiatannya.

Payung hukum yang saat ini masih dipakai dalam aturan pengelolaan parkir menggunakan Peraturan Daerah Kota Bandung Nomor 4 Tahun 2017 tentang Penyelenggaraan Perhubungan dan Retribusi di bidang Perhubungan. Aturan ini mengharuskan seluruh pendapatan dan retribusi $100 \%$ masuk ke kas daerah dan ketika ada lelang investasi mesin parkir pada mereka dibayar dari APBD. Karena dibayar oleh belanja APBD . Investor terkena pajak Pertambahan Nilai (PPN) sebesar 10\%. Selain itu juga ketika melakukan negosiasi dengan pihak bank yang menyediakan fasilitas cashless tidak memberikan jasa transaksi karena pendapatan retribusi harus masuk $100 \%$.

Maka berdasarkan agumentasi informan ketika ada skema kerjasama pemerintah-swasta otomatis beberapa peraturan harus diubah diantaranya terkait dengan retribusi. Pihaknya menilai konsep retribusi tidak memberikan keluwesan dalam melakukan orientasi pasar.

Dalam upaya meningkatkan layanan kepada publik, maka diperlukan pengaturan yang kelembagaan yang mendasar yaitu dengan mengubah Unit Pelaksana Teknis (UPT) yang sangat birokratis dan setiap proses dalam menjalankan kerja-kerja pelayanan sangat menggantungkan pada otritas pejabat.

Pada tahun 2020 perubahan dalam pengelolaan parkir sudah dimulai dengan mengubah nomenklatur UPT menjadi Badan Layanan Umum Daerah (BLUD) Parkir. Konsekuensinya BLUD ini cara kerjanya harus berdasarkan pada prinsip efisiensi dan produktivitas. Selanjutnya dalam Pola Pengelolaan Keuangan Badan Layanan Umum, yang selanjutnya disebut PPK-BLU, adalah pola pengelolaan keuangan yang memberikan fleksibilitas berupa keleluasaan untuk menerapkan praktek-praktek bisnis yang sehat untuk meningkatkan pelayanan kepada masyarakat dalam rangka memajukan kesejahteraan umum dan mencerdaskan kehidupan bangsa.

Unit Pelaksana Teknis (UPT) atau Unit Pelaksana Teknis Daerah (UPTD) yang telah menjadi BLUD memiliki perbedaan dalam mengelola kegiatan operasionalnya. Kegiatan operasional tersebut yaitu pengelolaan keuangan, Sumber Daya Manusia (SDM), pengadaan barang dan jasa, dan lain sebagainya. Setelah menjadi BLUD, terdapat beberapa hal yang perlu dipersiapkan oleh UPT untuk diimplementasikan terkait dengan pengelolaan kegiatan operasionalnya tersebut. Penyusunan Peraturan Kepala Daerah ini dilakukan oleh pimpinan Badan Layanan Umum Daerah (BLUD), Menyusun Surat Keputusan (SK) Kepala Daerah untuk beberapa hal yang mendukung pengelolaan operasional UPTdan Menyusun Peraturan Pemimpin BLUD diantaranya mengatur tentang engangkatan Bendahara Penerimaan dan Bendahara Pengeluaran yang Bersumber Non APBD/APBN serta peraturan lain yang diperlukan sesuai dengan kebutuhan masing-masing BLUD. Berdasarkan informasi meskipun sudah menjadi BLUD masih ada beberapa aturan yang belum dipenuhi sehingga masih belum memungkinkan untuk melakukan kerjasama dengan pihak ketiga.

Skema Kerjasama Pemerintah-swasta harus memperhatikan hubungan antar pihak yang terlibat dalam kebijakan pengelolaan parkir elektronik. Bentuk kerja sama merupakan tinjauan agar kemitraan KPS di-strukturkan untuk mengoptimalkan nilai bagi publik dan pada saat yang bersamaan tidak mengurangi minat dari mitra swasta. Pada umumnya, Bentuk Kerja Sama ini dilakukan sebagai bagian dari Studi Kelayakan. Bercermin pada awal pengadaan mesin parkir yang tadinya akan dilakukan dengan skema lelang investasi terjadi negosiasi yang a lot dengan kalkulasi bisni dengan pendapatan langsung bagi hasil adalah $70 \%$ untuk investor karena penyedia alat 30 $\%$ masuk ke kas daerah karena mata pendapatan retribusi ternyata bagi hasil tidak boleh.

Karena saat ini kondisinya sudah berubah memungkinkan dilakukan kembali skema lelang investasi tetapi untuk pengelolaan parkir. Informan menyampaikan selama masih belum dikelola oleh pihak ketiga pendapatan dari parkir masih tetap stagnan. Sebalik kalau dikelola secara professional oleh pihak ketiga seperti halnya DKI Jakarta maka pendapatan bisa sampai 4 kali lipat.

Hubungan antar pihak juga harus mempertimbangkan mitigasi resiko yang akan terjadi. Melakukan studi kelayakan dengan mendalam. Sehingga tidak ada lagi proses yang tiba-tiba hadir tanpa terpikirkan sebelumnya. Semua berdasarkan perhitungan yang matang dengan pendekatan win-win solution.

Sementara untuk Kota Cimahi dalam tingkat elastisitas tidak menemukan perubahan yang signifikan mulai dari pengelolaan pajak daerah masih dilakukan dengan cara yang manual. Tidak seperti di Kota Bandung yang sudah mengembangkan aplikasi e-satria dalam pelaporan bagi WP. Begitu juga dalam pengelolaan retribusi

Supaya mencapai tujuan optimalisasi pajak parkir maupun retribusi parkir dilakukan evaluasi tingkat efektivitas dalam menjalankan proses pemanfaatan sumberdaya yang berpotensi akan memudahkan tujuan tercapai.

Peneliti melihat langkah-langkah yang dilakukan oleh pemerintah Kota Bandung baik dalam pengelolaan pajak parkir maupun retribusi parkir mengarah pada upaya efektivitas. Diantaranya adalah BPPD melakukan upaya kolaborasi dengan instansi kewilayahan baik Kecamatan maupun kelurahan untuk melakukan pendataan. Selain itu, Bapenda juga memiliki 5 Unit Pelaksana Teknis untuk mendekatkan pelayanan wajib pajak. Sehingga langkah yang dilakukan lebih terstruktur dan sistematis. 
Begitu juga dalam pengelolaan retribusi parkir upaya untuk mengefektivkan proses dilakukan dengan mengubah parkir manual menjadi parkir elektronik. Meskipun memiliki catatn kritis untuk memperbaiki tata kelola parkir elektronik yang bisa memberikan peningkatan pendapatan. Selain itu perubahan kelembagaanpun dilakukan dengan mengubah UPT parkir menjadi Badan Layanan Umum Daerah. Konsekuensinya BLUD ini cara kerjanya harus berdasarkan pada prinsip efisiensi dan produktivitas. Selanjutnya dalam Pola Pengelolaan Keuangan Badan Layanan Umum, yang selanjutnya disebut PPK-BLU, adalah pola pengelolaan keuangan yang memberikan fleksibilitas berupa keleluasaan untuk menerapkan praktek-praktek bisnis yang sehat untuk meningkatkan pelayanan kepada masyarakat dalam rangka memajukan kesejahteraan umum dan mencerdaskan kehidupan bangsa.

Unit Pelaksana Teknis (UPT) atau Unit Pelaksana Teknis Daerah (UPTD) yang telah menjadi BLUD memiliki perbedaan dalam mengelola kegiatan operasionalnya. Kegiatan operasional tersebut yaitu pengelolaan keuangan, Sumber Daya Manusia (SDM), pengadaan barang dan jasa, dan lain sebagainya. Setelah menjadi BLUD, terdapat beberapa hal yang perlu dipersiapkan oleh UPT untuk diimplementasikan terkait dengan pengelolaan kegiatan operasionalnya tersebut. Penyusunan Peraturan Kepala Daerah ini dilakukan oleh pimpinan Badan Layanan Umum Daerah (BLUD), Menyusun Surat Keputusan (SK) Kepala Daerah untuk beberapa hal yang mendukung pengelolaan operasional UPTdan Menyusun Peraturan Pemimpin BLUD diantaranya mengatur tentang engangkatan Bendahara Penerimaan dan Bendahara Pengeluaran yang Bersumber Non APBD/APBN serta peraturan lain yang diperlukan sesuai dengan kebutuhan masing-masing BLUD. Berdasarkan informasi meskipun sudah menjadi BLUD masih ada beberapa aturan yang belum dipenuhi sehingga masih belum memungkinkan untuk melakukan kerjasama dengan pihak ketiga.

\section{KESIMPULAN}

Kesimpulan yang diperoleh dari hasil penelitian tentang studi kebijakan dalam optimalisasi pajak dan retribusi parkir adalah Pertama, Kebijakan Kota Bandung melakukan upaya elastisitas dan Efektivitas dengan pendataan, sosialisasi kepada wajib pajak dan pihak yang akan dianggap berpotensi menjadi WP baru. Potensi pajak parkir terus ditingkatkan oleh BPPD Kota Bandung dengan intensifikasi dan ekstensifikasi pajak. Kedua, Meskipun petugas sedikit. BPPD Kota Bandung selalu mengedepankan kolaborasi dengan 5 UPT dan dengan kantor kewilayahan yaitu kecamatan dan kelurahan. Tugasnya melakukan pendataan dan pelaporan terhadap potensi pajak parkir yang belum tergarap yaitu tempat penitipan kendaraan bermoto. Laju pertumbuhan pajak parkir maupun retribusi parkir selama tiga tahun trend nya meningkat kecuali tahun 2020 ini karena kondisi pandemic

\section{REFERENCES}

Arikunto, S. (2010). Metode peneltian. Jakarta: Rineka Cipta.

Harefa, M., Permana, S. H., Mangeswuri, D. R., \& Meilani, H. (2018). Optimalisasi kebijakan penerimaan daerah. Yayasan Pustaka Obor Indonesia.

Horota, P., Riani, I. A. P., \& Marbun, R. M. (2017). Peningkatan Pendapatan Asli Daerah dalam rangka Otonomi Daerah melalui potensi pajak dan retribusi daerah di Kabupaten Jayapura. Jurnal Kajian Ekonomi Dan Keuangan Daerah, 2(1).

Rante, A., Mire, M. S., \& Paminto, A. (2018). Analisis kemandirian keuangan daerah. INOVASI, 13(2), 78-89.

Sidik, M. (2002). Optimalisasi pajak daerah dan retribusi daerah dalam rangka meningkatkan kemampuan keuangan daerah. Makalah Disampaikan Acara Orasi Ilmiah. Bandung, 10.

Sulila, I. (2015). Implementasi dimensi layanan publik dalam konteks otonomi daerah. Deepublish.

Sutardi. (2005). Evaluasi Retribusi Parkir dan Kontribusinya Terhadap Pendapatan Asli Daerah Kabupaten Karanganyar (Periode Tahun 2001 - 2004). Universitas Sebelas Maret Surakarta. 